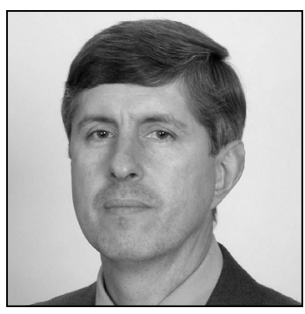

Leonid Tymchenko

Professor, Head of Project

Research Institute of

Financial Law, Ukraine

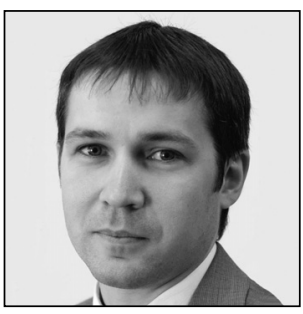

Pavlo Selezen

Associate Professor,

Senior Research Fellow

Irpin, Kiev Region, Ukraine

\title{
The Concept of Beneficial Owner in Application of the Ukrainian Double Taxation Treaties
}

\section{Introduction}

The provisions on beneficial owner status in the national legislation of Ukraine appeared at the dawn of the country's independence. According to Article 7 of the Law on Succession (1991), Ukraine is a successor taking on rights and obligations under international treaties of the USSR unless they contradict its constitution and the interests of the republic. ${ }^{*}$ Such a position of national legislator determined the inclusion of the double taxation treaties of the former USSR in the Ukrainian legal system in 1991. Most of these treaties contained provisions on beneficial ownership pertaining to the taxation of passive income at the moment of their recognition as a part of the Ukrainian legal system. Nevertheless, the provisions on beneficial owners in double taxation treaties had not been referred to in tax disputes until the moment of the Tax Code of Ukraine taking effect, in 2011. They allow the use of provisions related to the status of beneficial owner in the process of giving access to treaty benefits.

The changing nature of the concept of beneficial owner, its importance as an instrument for counteraction of treaty shopping, and the necessity of improvement of its application in the Ukrainian reality are the main factors that have a strong impact on the development of the concept of beneficial owner in Ukraine. This article focuses on the issues of normative basis and court interpretation of 'beneficial owner' in tax treaty disputes. The objective for the article is to characterise modern tendencies and the main obstacles in application of the national provisions on beneficial owners since the adoption of the Tax Code of Ukraine.

\section{The appearance of the concept of beneficial owner in the Tax Code of Ukraine}

Article 103 (2) of the Tax Code of Ukraine states that a person (tax agent) has a right to use tax exemption or to lower his or her tax rate in accordance with the provisions of a double taxation treaty of Ukraine in

1 Про правонаступництво України ['Law on succession of Ukraine’]. - Закон Украйни No. 1543-XII, 12.9.1991. Available at http://zakon2.rada.gov.ua/laws/show/1543-12 (most recently accessed on 17.7.2015) (in Ukrainian). 
the case of paying income to a non-resident only if the latter is the beneficial owner of that income and the resident of a state that has entered into a double taxation treaty with Ukraine. ${ }^{{ }_{2}}$ This provision is unique in the tax legislation of Ukraine because it marked the first time when the national legislator prescribed the application of the provisions on beneficial owners in tax relations, at the moment of adoption of the Tax Code of Ukraine. It also determines further development of the concept of beneficial owner in the practice of tax authorities and courts.

The Ukrainian experience with application of the concept of beneficial owner in taxation of foreign income is developing in line with the necessity of limiting widespread usage of treaty shopping by taxpayers. For example, an expert with VoxUkraine, Zoya Milovanova, states that Ukraine loses about 6 billion hryvnas every year from the existence of a double taxation treaty with Cyprus, which is only one of the 70 double taxation treaties signed by Ukraine. ${ }^{*}$ It is worth mentioning that Cyprus is the biggest investor in the national economy of Ukraine (direct foreign investments from Cyprus were equivalent to 13,710.6 million US dollars in $2014^{*}$ ).

The attempt to decrease the level of treaty shopping by Ukrainian taxpayers with the aid of the concept of beneficial owner was inspired by that concept's widespread usage in the modern world. Inclusion of norms on beneficial ownership in double taxation treaties dates back to the 1940 s. $^{*}{ }^{*}$ The main impulse for their active application in tax treaty practice was given by the introduction of analogous provisions in the OECD Model Double Taxation Convention on Income and Capital (1977). Treaty provisions on beneficial owners have the long history of application notwithstanding there is no uniform and stable understanding of their key elements proceeding from the general and limited approach that is covered in commentary to Articles 10, 11, and 12 of the OECD Model Tax Convention on Income and on Capital (2014). It has to be mentioned that even these articles 'illustrate the (negative) meaning of the term' and do not 'define it exhaustively'. ${ }^{*}$ The situation seems even more complicated if one takes into account periodic changes in the interpretation of the concept of beneficial owner. For example, the last one was made in accordance with the 2014 Update to the OECD Model Tax Convention. ${ }^{*}$

\section{The normative basis of the concept of beneficial owner in the Ukrainian tax legislation}

The Ukrainian legislator has included the meaning of the term 'beneficial owner' in Article 103 (3) of the Tax Code of Ukraine. It prescribes that the term 'beneficial owner' in connection with gaining access to double taxation treaty benefits could be interpreted as referring to a person with a right to receive income from sources in Ukraine. There is also a list of persons that may not be deemed beneficial owners of income in any case. These are agents, nominees, or mere intermediaries with respect to the income to which the lowered rate of tax is potentially applicable under the rules of the double taxation treaty. ${ }^{* 8}$

The approach of the Ukrainian legislator is not very special in the context of the general and widespread interpretation of the term 'beneficial owner' in accordance with the commentaries considering Articles 10,

2 Податковий кодекс України (Tax Code of Ukraine), No. 2755-VI, 2.12.2010. Available at http://zakon4.rada.gov.ua/laws/ show/2755-17 (most recently accessed on 17.7.2015) (in Ukrainian).

3 З. Мілованова (Z. Milovanova). Кіпрське питання. Боротьба з офшором чи з інвестиціями? [‘The issue of Cyprus: Is it a fight with the offshore or with investments?']. Available at http://www.eurointegration.com.ua/articles/2014/12/30/7029262/ view_print/ (most recently accessed on 17.7.2015) (in Ukrainian).

4 Інвестицї̈ зовнішнъоекономічної діяльності Украӥни. Статистичний збірник ['Investments of Foreign Economic Activity of Ukraine: Statistical Volume']. Kiev: State Service of Statistics of Ukraine 2015, p. 14. Available at https://ukrstat. $\mathrm{org} / \mathrm{uk} / \mathrm{druk} /$ publicat/kat_u/2015/zb/04/zb_izd_pdf.zip (most recently accessed on 17.7.2015) (in Ukrainian).

5 R. Vann. Beneficial ownership: What does history (and maybe policy) tell us. Sydney Law School Research Paper No. 12/66, September 2012, p. 5. Available at http://ssrn.com/abstract=2144038 (most recently accessed on 17.7.2015).

6 L. de Broe. International Tax Planning and Prevention of Abuse under Domestic Tax Law, Tax Treaties and EC law: A Study of the Use of Conduit and Base Companies (thesis submitted to the K.U. Leuven Faculty of Law, in fulfillment of the requirements for the degree of Doctor in de Rechten). Leuven, Belgium: Katholieke Universiteit Leuven 2007, p. 501.

72014 Update to the OECD Model Tax Convention, OECD (77 p.). Available at http://www.oecd.org/ctp/treaties/2014-updatemodel-tax-concention.pdf (most recently accessed on 17.7.2015).

8 Податковий кодекс України (see Note 2). 
11, and 12 of the OECD Model Tax Convention on Income and on Capital. ${ }^{*}$ Nevertheless, there are a few traits characteristic of interpretation of the term 'beneficial owner' in the Tax Code of Ukraine. These are connected with:

- the scope of the demand for beneficial ownership of the income;

- applicability of the demand that one be the beneficial owner of the income in relation to double taxation treaties that are in effect in accordance with the fact of succession in respect of international treaty obligations of the USSR; and

- application of the modern meaning of the term 'beneficial owner' in relation to treaties entered into earlier.

\subsection{The scope of the demand for beneficial ownership of the income}

Under Article 103 (3) of the Tax Code of Ukraine, the demand pertaining to being the beneficial owner of the income is applicable to payments in the form of dividends, interest, royalties, remuneration, etc. It is worthwhile to mention the openness of the list of kinds of income to which the demand for beneficial ownership of the income could be applicable. It is unusual in the context of international experience and the rules of double taxation treaties.

According to the provisions of Articles 10, 11, and 12 of the OECD Model Tax Convention on Income and on Capital, the scope of the demand of beneficial ownership of income is limited to those situations in which the payments are made only in the form of dividends, interest, and royalties. There are no provisions in the text of the OECD Model Tax Convention on Income and on Capital that prescribe the application of the requirement of beneficial ownership to other kinds of income. This is the approach that most countries follow in their double taxation treaties, Ukraine included. Exceptions from this rule are rare in treaty practice (with India representing one of them [ $\left.{ }^{*} 10\right]$ ).

According to Philip Baker, from a conceptual point of view, 'there is no reason in principle why the beneficial ownership concept should be limited' to articles on taxation of dividends, interest, and royalties. He explains that if other treaty provisions allow access to treaty benefits in the form of taxation in only one of the contracting states, they could 'attract treaty shopping, particularly if the item of income, income gain or capital is subject to a low level of taxation, or no taxation, in the other Contracting State'. ${ }^{* 11}$ The Ukrainian legislator was following the same logic when deciding to extend the scope of the demand for beneficial ownership to other types of income.

Application of the demand for beneficial ownership in situations of paying income other than dividends, interest, or royalties could be problematic under the Vienna Convention on the Law of Treaties (1969) if such application is not determined by the treaty norms themselves. This implication is connected with the obligations under Article 27 of the Vienna Convention on the Law of Treaties, according to which 'a party may not invoke the provisions of its internal law as justification for its failure to perform a treaty'. ${ }^{12}$ Even if, for reason of non-participation in the Vienna Convention on the Law of Treaties, the countries are not obliged to apply its terms, they have the same obligations because Article 27 reflects 'well-established customary rule'. ${ }^{13}$ In consequence, the approach of the Ukrainian legislator to the scope of the demand for beneficial ownership of the income is not justifiable, because it is contrary to the obligations under the Vienna Convention on the Law of Treaties, to which Ukraine is a party.

9 Model Tax Convention on Income and on Capital: Condensed Version 2014. Paris: OECD Publishing 2014, pp. 188?191, 213?215, 224?227. Available at http://www.keepeek.com/Digital-Asset-Management/oecd/taxation/mod el-tax-convention-on-income-and-on-capital-condensed-version-2014_mtc_cond-2014-en (most recently accessed on 17.7.2015).

10 E. Reimer, A. Rust (eds). Klaus Vogel on Double Taxation Conventions. 4th ed., Vol. 1. Alphen aan den Rijn, Netherlands: Wolters Kluwer 2015, p. 740.

11 Note by the Coordinator of the Subcommittee on Improper Use of Treaties: Proposed amendments, UN Committee of Experts on International Cooperation, E/C.18/2008/CRP.2/Add.1, 17.10.2008, p. 17. Available at http://www.un.org/esa/ffd/wpcontent/uploads/2014/10/4STM_EC18_2008_CRP2.pdf (most recently accessed on 20.7.2015).

12 Vienna Convention on the Law of Treaties. Vienna, 23.5.1969. Available at https://treaties.un.org/doc/Publication/UNTS/ Volume\%201155/volume-1155-I-18232-English.pdf (most recently accessed on 20.7.2015).

13 See the Pulp Mills on the River Uruguay (Argentina $v$. Uruguay), judgment, I.C.J. Reports 2010, p. 14, para. 121. Available at http://www.icj-cij.org/docket/files/135/15877.pdf (most recently accessed on 20.7.2015). 


\subsection{Applicability of the demand for beneficial ownership of the income in relation to double taxation treaties of the ex-USSR still in effect}

As is mentioned above, Ukraine is one of the successors to rights and obligations under international treaties of the USSR where these do not contradict its constitution and the interests of the republic. The status of these treaties is not comprehensively defined, either by the Constitution of Ukraine or by its national legislation. There are three double taxation treaties that were entered into by the former USSR and have remained in force thus far - with Spain, Malaysia, and Japan. ${ }^{* 14}$

The issue of succession to treaty rights and obligations of the former USSR is not highlighted in the Constitution of Ukraine. Its Article 9 regulates the legal status of international treaties of Ukraine in the national legal system but remains silent with regard to the legal status of treaties of the former Soviet Union. It states only that international treaties that are in force and agreed upon as binding by the Verkhovna Rada of Ukraine are part of the national legislation of Ukraine. ${ }^{*} 15$ It should be noted that 'the Verkhovna Rada of Ukraine has received a right to give consent to be bound by international treaty since 17th September 1991. ${ }^{*}{ }^{16}$ In consideration of the fact that the double taxation treaties of the former USSR had been ratified before that moment, it is obvious that they could not meet the requirements set in Article 9 of the Constitution of Ukraine.

The problems with the legal status of treaties of the former USSR seem to be more complicated if one tries to define the content of the term 'national legislation' as used in Article 9 of the Constitution of Ukraine. The Constitutional Court of Ukraine interprets this term as encompassing 'laws of Ukraine [and] international treaties in force that are agreed upon as binding by the Verkhovna Rada of Ukraine, resolutions of the Verkhovna Rada of Ukraine, decrees of the President of Ukraine, [and] decrees and resolutions of the Cabinet of Ministers of Ukraine'. ${ }^{*}{ }^{*}$ In accordance with this position, the treaties of the former USSR that continue to be in effect in Ukraine cannot be deemed a part of its national legislation.

On the basis of detailed analysis of Article 9, A. Melnyk concludes that 'if [...] we follow the content of Article 9 of the Constitution of Ukraine, international treaties of the former USSR could not seem a part of the national legislation. ${ }^{*}{ }^{18}$

Despite the undefined status of international treaties of the former USSR that are still in effect, the national legislator decided to use a similar approach to formulation of terms in Article 3 (2) of the Tax Code of Ukraine. This states that if an international treaty that is in force and agreed upon as binding by the Verkhovna Rada of Ukraine prescribes other rules than do provisions of the Tax Code of Ukraine, the rules of said international treaty should be applicable. As has been pointed out above, international treaties of the former USSR do not meet the criteria for having been agreed upon to be binding by the national Parliament because this was beyond its competence at the time of the Ukrainian SSR. Moreover, these treaties are not regarded as a part of national legislation according to Article 3 (1) of the Tax Code of Ukraine in the case of a formalistic approach to its interpretation.

As in the case of the scope of the demand for existence of beneficial ownership of the income, Article 27 of the Vienna Convention on the Law of Treaties helps give effect to the double taxation treaties of the former USSR in the Ukrainian legal system even if the national legislator mentions them neither in the Constitution of Ukraine nor in the Tax Code of Ukraine. Nonetheless, Article 27 does not assist in solving

14 Лист Державної фіскальної служби України щодо міжнародних договорів про уникнення подвійного оподаткування ['Letter of the State Fiscal Service of Ukraine on double taxation treaties], No. 2809/7/99-99-12-01-03-17, 20.1.2015. Available at http://sfs.gov.ua/diyalnist-/mijnarodne-/chinni-dvostoronni-mijuryado/196979.html (most recently accessed on 20.7.2015) (in Ukrainian).

15 Constitution of Ukraine, adopted at the Fifth Session of the Verkhovna Rada of Ukraine on 28 June 1996. Available at http:// www.infoukes.com/history/constitution/index-en.html (most recently accessed on 20.7.2015).

16 М. Буроменский (M. Buromenskiy). Действие международных договоров Украины во внутреннем правопорядке Украины ['Application of international treaties of Ukraine in the national legal order']. Available at http://www.judges.org. ua/article/seminar9-1.htm (most recently accessed on 20.7.2015) (in Russian).

17 Рішення Конституційного Суду України у справі про тлумачення терміну 'законодавство' ['Judgement of the Constitutional Court of Ukraine in the case on interpretation of the term "legislation”'], No. 12-pп/98, 9.7.1998, para. 1. Available at http://zakon1.rada.gov.ua/laws/show/v012p710-98 (most recently accessed on 20.7.2015) (in Ukrainian).

18 А. Мельник (А. Melnyk). Правонаступництво України щодо міжнародних договорів колишнього СРCP ['Succession of Ukraine in respect of international treaties of the former USSR'], a thesis submitted to the Legislation Institution of the Verkhovna Rada of Ukraine, in fulfillment of the requirements for the degree of Candidate of Sciences. Kiev, 2004, p. 175 (in Ukrainian). 
the problem of applicability of the demand for beneficial ownership under Article 103 of the Tax Code of Ukraine in connection with double taxation treaties entered into by the former Soviet Union.

If the double taxation treaties of the former USSR are not part of the national legislation of Ukraine, one must conclude that the demand of beneficial ownership could not be applicable in a situation of gaining access to the associated treaty benefits in accordance with Article 103 of the Tax Code of Ukraine. The provisions of Article 103 of the Tax Code of Ukraine use the term 'international treaty of Ukraine'; they do not make reference to the double taxation treaties of the former USSR. This means that the application of the demand pertaining to being a beneficial owner of income in order for one to benefit from double taxation treaties of the former USSR needs additional justification.

\subsection{Application of the modern meaning of the term 'beneficial owner' in relation to treaties entered into earlier}

The tax authorities of Ukraine agree with the possibility of interpretation of the term 'beneficial owner' in accordance with the commentaries to the OECD Model Tax Convention on Income and on Capital and the UN Model Double Taxation Convention between Developed and Developing Countries. ${ }^{* 19}$ This position does not give a clear answer to the question of which edition of these models should be used in any concrete case. For example, the concept of beneficial owner was changed in 1986, 2003, and 2014. Is it possible to interpret the term 'beneficial owner' in accordance with the commentaries to the OECD Model Tax Convention on Income and on Capital in its 2014 edition in a case of double taxation treaties entered into previously? The answer is still open in Ukraine, because neither courts nor tax authorities make reference to this issue.

There are three main approaches to the issue among researchers. The first of them is represented by the position of K. Vogel, who has stated that 'changes in the Commentaries after the conclusion of the tax Treaty can neither amend the treaty [...] nor retroactively determine its interpretation'. ${ }^{*}{ }^{20}$ This view is shared by G. Hill, with his statement that 'it would seem a difficult matter, absent any consensus of the contracting states, to regard commentary after ratification in the same way as a commentary before' because the commentary in its newer form was not taken into account by the parties to the double taxation treaty at the moment of adoption of the particular provision in question. ${ }^{{ }^{21}}$

The second approach is supported by R. Vann. He notes that Article 31 (3) of the Vienna Convention on the Law of Treaties allows subsequent agreements and practice to be taken into account together with the context. Accordingly, he regards as justified the statement that later commentaries on the OECD Model Tax Convention on Income and on Capital should be considered to reflect a subsequent agreement or later practice of the contracting states. ${ }^{* 2}$

The third approach is proposed by L. de Broe. His position is reflected in the statement that there is little or no justification to give weight to new Commentary - other than Commentary that does not go beyond a fair interpretation of the text of a particular treaty - to interpret provisions of pre-existing treaties. ${ }^{*}{ }^{23} \mathrm{He}$ admits that a new commentary could be used as an interpretation tool if subsequent changes reflect the practice of the contracting states and are a genuine interpretation of a treaty rather than changes to its provisions. ${ }^{*} 4$

It is worthy of mention that the introduction to the OECD Model Tax Convention on Income and on Capital states that amendments to its provisions and the commentaries are not relevant for the interpretation of

19 Лист Державної податкової адміністрації України щодо тлумачення терміну ‘бенефіціарний власник’ ['Letter of the State Tax Administration of Ukraine on interpretation of the term "beneficial owner"'], No. 3917/5/12-0216, 30.3.2011. Available at http://www.profiwins.com.ua/uk/letters-and-orders/gna/3097-3917.html (most recently accessed on 20.7.2015) (in Ukrainian).

20 K. Vogel. The influence of the OECD commentaries on treaty interpretation. - Bulletin for International Taxation 54 (2000) / 12, p. 615.

21 G. Hill. The interpretation of double taxation agreements - the Australian experience. - Bulletin for International Taxation 57 (2003) / 8, p. 325.

22 R. Vann. Interpretation of tax treaties in New Holland. Legal Studies Research Paper No. 10/121, November 2010 , p. 8. Available at http://ssrn.com/abstract=1704890 (most recently accessed on 17.7.2015).

23 L. de Broe (see Note 6), p. 271.

24 Ibid. 
previously entered into double taxation treaties if the provisions of these treaties are different in substance from the amendments. ${ }^{*} 25$ At the same time, additions or other changes to the commentaries might be applicable in the interpretation of previously entered into double taxation treaties. The main argument stems from the fact that these amendments reflect the consensus of the OECD member countries as to the proper interpretation of existing provisions and their application to specific situations. Nevertheless, the OECD Model Tax Convention on Income and on Capital and the commentaries are not binding instruments but can be of great assistance in the application and interpretation of double taxation treaties. ${ }^{*} 6$

\section{Tendencies in the development of the concept of beneficial owner in court practice}

Neither the commentary to the OECD Model Tax Convention on Income and on Capital nor the Ukrainian tax legislation expressly defines the term 'beneficial owner'. In this situation, Ukrainian courts are challenged with the need to determine the meaning of the term in particular cases. It also has to be pointed out that the meaning of 'beneficial owner' is elusive under the domestic law of most countries and that 'civil law countries do not use this concept, creating an issue of compatibility of the transplanted treaty concept with domestic law'.*27

As one can see from the summary of Ukrainian courts' practice provided below, it is possible to emphasise two main traits in the approach of the courts to interpretation of provisions on beneficial ownership in double taxation treaties:

- movement from using a narrow technical meaning of the term 'beneficial owner' to its interpretation in light of the context, objects, and purposes of double taxation treaties

- uncertainty on the question of the applicability of treaty benefits in a case wherein the beneficial owner and intermediary are residents of the same contracting state

\subsection{Alternative approaches to interpretation of the term 'beneficial owner' in court practice}

According to Article 103 (3) of the Tax Code of Ukraine, the meaning of the term 'beneficial owner' does not include agents, nominees, or mere intermediaries. It is obvious that the provisions of the Tax Code of Ukraine do not make reference to a list of certain criteria for determining a status of beneficial owner that could be decisive. This situation has influenced the active role of judges in the development of the concept of beneficial owner in cases pertaining to double taxation treaties.

Ukrainian court practice has developed two main approaches to interpretation of the term 'beneficial owner'. As is mentioned by I. Kalnytska and O. Michaylenko, each of these approaches is based on existing world tendencies in the interpretation of the term. ${ }^{*} 8$ These approaches reflect the existence of the controversial question of whether it should have a domestic-law meaning or instead an international meaning. ${ }^{*} 9$

In accordance with the first approach, the Ukrainian tax authorities try to apply the provisions of the Tax Code of Ukraine under which agents and intermediaries are not beneficial owners, particularly in cases of sub-licence agreements and royalties. Usually, the courts do not support the position of the tax authorities in cases involving sub-licencing agreements, for two reasons. Firstly, sub-licence agreements approve contractual rights of recipients of income from Ukraine and thereby grant these persons the status of beneficial owner of the income. Secondly, the courts do not accept the references of tax authorities to Article 103 (3) of the Tax Code of Ukraine, because grounds do not exist for these. Sub-licence agreements do not

25 Model Tax Convention on Income and on Capital: Condensed Version 2014 (see Note 9), pp. 15-16.

26 Ibid., p. 14.

27 J. Li. Beneficial ownership in tax treaties: Judicial interpretation and the case for clarity - comparative research in law and political economy. Research Paper No. 4/2012, p. 189. Available at http://digitalcommons.osgoode.yorku.ca/clpe/4 (most recently accessed on 20.7.2015).

28 I. Кальницька, О. Михайленко (I. Kalnytska, O. Michaylenko). Ідентифікація бенефіціара ['Identification of beneficial owner']. - Судовий вісник 2014/9, p. 15 (in Ukrainian).

29 J. Li (see Note 24), p. 198. 
regulate the activity of agents or intermediaries according to the civil law of Ukraine. For an example of this approach, one could point to the decision of the Supreme Administrative Court of Ukraine in the Semki case. ${ }^{*} 30$

The other approach has been proposed as a result of wider interpretation of the term 'beneficial owner'. Its main characteristics were formulated by the Supreme Administrative Court of Ukraine in the decision on the Donbasaero case, from March 2014. ${ }^{*}{ }^{11}$ Judges noted that the term 'beneficial owner' should not be interpreted in a narrow and technical sense, because of the necessity to take into account the object and purposes of double taxation treaties, including both avoidance of double taxation and prevention of abuses of treaty provisions. The idea is that to be a beneficial owner, one should not be a mere recipient of income but a person able to 'determine the further economic destination of the income'. This approach is supported by the Ukrainian tax authorities. The State Fiscal Service of Ukraine explains that treaty benefits could not be applied if a non-resident acts as an intermediate party on behalf of the real beneficial owner that actually enjoys the income. For example, lower rates of taxation in the country of origin could not be applicable if a non-resident receives dividends, interest, or royalties; has very limited rights in relation to such income; and directs them fully or mostly to the other non-resident, who does not have access to treaty benefits. ${ }^{*{ }^{*}} 32$ The common position of the tax authorities and courts reassures R. Blazhko that such an approach will dominate for the near future ${ }^{*} 33$ It is worthwhile to mention that the second approach to interpretation of the term 'beneficial owner' is in accordance with the commentaries to the OECD Model Tax Convention on Income and on Capital. ${ }^{*} 34$

\subsection{Applicability of treaty benefits in cases wherein the beneficial owner and intermediary are residents of the same contracting state}

According to the commentaries to the OECD Model Tax Convention on Income and on Capital, 'limitation of tax in the State of source remains available when an intermediary, such as an agent or nominee located in a Contracting State or in a third State, is interposed between the beneficiary and the payer' on the condition that the beneficial owner is a resident of the other contracting state. ${ }^{*} 35$ In other words, if the beneficial owner of the income and an intermediary are residents of the same contracting state, the treaty benefits could be available on condition of the existence of a double taxation treaty between that contracting state and the state of the source of income.

There is no clarity on this question in Ukraine. The Ukrainian courts have not considered this issue so far, but the possibility of its appearance has remained. ${ }^{*} 36^{*} 37$ The absence of court practice in this context does not mean that similar problem pertaining to the applicability of treaty benefits are not going to appear in the near future. The position of the beneficial owner is grounded in the status of resident of the contracting state, so it must be permissible to gain access to treaty benefits under a double taxation treaty with the country of the source of income. Otherwise, double taxation of the income of the beneficial owner rears its head because of taxation of the same income in the country of source and the country of residence. This practice is contrary to the primary purpose of double taxation treaties - to avoid double taxation.

30 Decision of the Supreme Administrative Court of Ukraine in case 2a/0470/15215/11, 21.5.2013. Available at http://www. reyestr.court.gov.ua/Review/31368171 (most recently accessed on 20.7.2015) (in Ukrainian).

31 Decision of the Supreme Administrative Court of Ukraine in case 805/7337/13-f, 24.3.2014. Available at http://reyestr. court.gov.ua/Review/38106136 (most recently accessed on 20.7.2015) (in Ukrainian).

32 Лист Державної фіскальної служби України щодо тлумачення терміну ‘бенефіціарний власник’ ['Letter of the State Fiscal Service of Ukraine on interpretation of the term "beneficial owner"'], No. 9033/7/99-99-10-02-02-17, 31.10.2014. Available at http://www.profiwins.com.ua/uk/letters-and-orders/gna/5296-9033.html (most recently accessed on 20.7.2015) (in Ukrainian).

33 Р. Блажко (R. Blazhko). Бенефіціарний власник: український підхід ['Beneficial owner: Ukrainian approach']. Available at http://taxua.blogspot.com/ (most recently accessed on 20.7.2015) (in Ukrainian).

34 Model Tax Convention on Income and on Capital: Condensed Version 2014 (see Note 9), pp. 188-189, 213, 224.

35 Ibid., pp. 191, 215, 227.

36 Decision of the Supreme Administrative Court of Ukraine in case K/800/52155/13, 24.3.2014. Available at http://www. reyestr.court.gov.ua/Review/38106136 (most recently accessed on 20.7.2015) (in Ukrainian).

37 Decision of the Lviv Circuit Administrative Court in case 813/8083/13-a. Available at http://www.reyestr.court.gov.ua/ Review/37813661 (most recently accessed on 20.7.2015) (in Ukrainian). 


\section{Conclusions}

World experience shows that the concept of beneficial owner employed in double taxation treaties is not easy to use. There is not even uniformity with regard to views of its purpose among modern states. ${ }^{*} 38{ }^{*} 39$ This means that the application of this concept could differ substantially among contracting states. In these conditions, every state should choose its own way of interpreting the term 'beneficial owner', in accordance with the demands of international and domestic law.

Ukraine has applied the concept of beneficial owner since 2011. The practice of its application is not very effective, because of complexity and the absence of previous experience. This may be exacerbated by the existence of difficult issues related to interpretation of the term 'beneficial owner' under the Tax Code of Ukraine, coupled with some uncertain elements in the development of domestic court practice. The unsatisfactory results of application of the concept of beneficial owner mean that it has to be clarified in the near future because of the task of limiting the scope of treaty shopping.

S. Baum, G. Watson. Beneficial ownership as a treaty anti-avoidance tool? - Canadian Tax Journal 60 (2012) / 1, p. 168.

39 K. Van Raad. Report on beneficial ownership under the OECD model convention and commentaries, pp. 3-4. Available at http://ibdt.org.br/material/arquivos/Atas/jfb_20111020093958.pdf (most recently accessed on 20.7.2015). 